\title{
Removal of Nitrogen Compounds from Wastewater in SBR Reactors with Brenntaplus VP1
}

\author{
Joanna Smyk ${ }^{1}$, Katarzyna Ignatowicz ${ }^{1 *}$ \\ 1 Bialystok University of Technology, Faculty of Civil and Environmental Engineering, Department of \\ Technology in Engineering and Environmental Protection, Wiejska 45E, 15-351 Białystok, Poland \\ * Corresponding author's e-mail: izoplana@gmail.com
}

\begin{abstract}
The paper presents the efficiency of nitrogen removal from wastewater using Brenntaplus VP1 as an external carbon source. The study was conducted during the municipal wastewater treatment process in two independent activated sludge chambers of SBR type. One of the chambers contained glycerol as the source of easily available organic compounds. The study showed that the use of Brenntaplus VP1 as the external carbon source during wastewater treatment resulted in a higher efficiency of nitrogen removal than in the reactor without the external carbon source applied, resulting in low level of the COD value in the treated wastewater. There was a significant acceleration of the denitrification process as compared to the control reactor.
\end{abstract}

Keywords: Brenntaplus VP1, carbon source, denitrification, reactor SBR

\section{INTRODUCTION}

Removing nitrogen from sewage is one of the main goals of the wastewater treatment plant [Zhang Y. et al. 2016]. The denitrification process, i.e. reduction of oxidized nitrogen compounds, is carried out by heterotrophic microorganisms that use nitrate $\left(\mathrm{NO}_{3}\right)$ or nitrite $\left(\mathrm{NO}_{2}\right)$ as the terminal hydrogen acceptors in the absence of oxygen. During this process, intermediates such as NO, $\mathrm{N}_{2} \mathrm{O}$ or gaseous $\mathrm{N}_{2}$ are formed [Kaszubowska M. et al., 2011]. One of the main reasons for the unsatisfactory effects of nitrogen removal in treatment plants is the shortage of organic carbon compounds, which limits the course of denitrification. In such cases, it may be necessary to add external carbon sources to the system that is readily absorbed by microorganisms [Cherchi $\mathrm{C}$ et al., 2009; Liu F. et al,. 2016; Dinçer K., Kargi F., 2000; Oleszkiewicz J.A et al., 2004; Shi Y. et al., 2017; Sun H et al., 2017].

At present, many wastewater treatment plants support denitrification using alternative carbon sources such as methanol, ethanol, acetic acid or glucose [Cherchi C et al., 2009; Elefsiniotis
P., Li D., 2006; Plüg B.D. et al., 2015; Zhang Y. et al., 2016; Smyk J., Ignatowicz K., 2017]. There are also certain preparations designed for sewage treatment plants including, among others, Brenntaplus VP1, which was developed to support the biological removal of biogenic compounds. According to the manufacturer, these preparations are not hazardous materials, are nonpoisonous, inflammable, non-explosive, are not waste products, can be used throughout the entire year, remain stable during storage, are completely biodegradable, and have a high COD content at the level of $1,000,000 \mathrm{mgO}_{2} / \mathrm{dm}^{3}$. The additional advantage is that this type of mixture guarantees superior species diversity in the activated sludge, rather than using methanol or ethanol alone, and has a very short adaptation time [Brenntaplus VP1 - producer's website, Ignatowicz K. et al., 2015].

According to literature data, the preparation can be successfully used in the sewage flow treatment plants [Simson G., 2009; Kogut P. at al., 2014; Ignatowicz K. et al., 2015]. The study was carried out to examine how Brenntaplus VP1, used as an external carbon source for wastewater treatment, affects the efficiency of removing nitrogen forms from wastewater in SBRs. 


\section{METHODS}

The study was conducted during the municipal wastewater treatment process in two independent SBR-activated sludge reactors. The active capacity was $10 \mathrm{dm}^{3}, 6.5 \mathrm{dm}^{3}$ was the activated sludge provided by the sewage treatment plant in Białystok, while the remaining quantity originated from the raw mechanically treated wastewater $\left(3.5 \mathrm{dm}^{3}\right)$ that was also obtained from the sewage treatment plant in Białystok.

A single cycle of the reactor lasted for 6 hours and included following phases: sewage supply (2 $\mathrm{min}$ ), mixing (anaerobic) (60 $\mathrm{min}$ ), aeration (3.5 $\mathrm{h})$, sedimentation ( $1 \mathrm{~h})$, and decantation $(0.5 \mathrm{~h})$. During the aeration phase, the compressed air was fed through the diffuser placed at the bottom of the rector; depending on the operating phase, the amount of air was from 0.1 to $3.0 \mathrm{mg} \mathrm{O}_{2} / \mathrm{dm}^{3}$, concentration of the activated sludge $3.5 \mathrm{~kg} / \mathrm{m}^{3}$, sludge index oscillated within $120-150 \mathrm{~cm}^{3} / \mathrm{g}$, hydraulic load of the chamber was $1.4 \mathrm{~m}^{3} / \mathrm{m}^{3} \mathrm{~d}$, whereas the pollution load amounted to $0.2 \mathrm{~kg}$ $\mathrm{COD} / \mathrm{m}^{3} \mathrm{~d}$. Brenntaplus VP1, as a source of easily available organic compounds, in an amount of $100 \mathrm{mg} / \mathrm{dm}^{3}\left(8-12 \mathrm{~g}\right.$ carbon source $\left./ 1 \mathrm{gNO}_{3}^{-}\right)$ wastewater was added into one of the chambers in each cycle, twenty minutes after the sewage pouring. Table 1 shows the parameters of SBR operation.

The collected sewage samples were filtered immediately after the filtration. Each filtrate was subject to determination of the following items in accordance with the applicable methodology:

- $\mathrm{ChZT}_{\mathrm{Cr}}$ - dichromate PN-ISO 15705:2005,

- $\mathrm{BZT}_{5}$ - manometric applying OxiTop Standard system,

- $\mathrm{N}_{-} \mathrm{NH}_{4}$ - spectrophotometry according to PN-ISO 7150-1:2002,
- $\mathrm{N}_{-} \mathrm{NO}_{3}-$ spectrophotometry according to PN-82/C-04576/08,

- Nog. - spectrophotometry according to PN-EN ISO 6878:2006,

- Pog. - spectrophotometry according to PN-C-04576-00:1973P,

- $\mathrm{P}_{-} \mathrm{PO}_{4}-$ spectrophotometry according to PN-EN ISO 6878:2006.

\section{RESULTS AND DISCUSSION}

Results of the R1 reactor effluent tests without the addition of an external carbon source were included in Table 1, while Table 2 shows results of the wastewater tests from R2 reactor with Brenntaplus VP1 as external carbon source. In Figure 1, the ratio of COD to total nitrogen at the individual control points was compared. According to the ATV guidelines, Henze, Spindor, Lomotovsky and other authors, denitrification occurs without interruption if the $\mathrm{COD} / \mathrm{N}$ ratio is from 4 to 10 . The $\mathrm{COD} / \mathrm{N}$ ratio in wastewater in both SBRs was insufficient for the denitrification process and was below the recommended range. The addition of Brenntaplus VP1 did little to improve this dependence and the $\mathrm{COD} / \mathrm{N}$ ratio almost reached the required lower limit of the range.

Table 1. Parameters of SBR operation.

\begin{tabular}{|l|l|}
\hline $\begin{array}{l}\text { Activated sludge } \\
\text { concentration }\end{array}$ & $3.5 \mathrm{~kg} / \mathrm{m}^{3}$ \\
\hline Sludge index & $120-150 \mathrm{~cm}^{3} / \mathrm{g}$ \\
\hline Hydraulic load of chamber & $1.4 \mathrm{~m}^{3} / \mathrm{m}^{3} \mathrm{~d}$ \\
\hline Load with impurities & $0.2-0.3 \mathrm{~kg} \mathrm{COD} / \mathrm{m}^{3} \mathrm{~d}$ \\
\hline Decantation coefficient & 0.3 \\
\hline
\end{tabular}

Table 2. Data and test results of wastewater without an addition of an external carbon source

\begin{tabular}{|c|c|c|c|c|c|c|c|}
\hline \multicolumn{8}{|c|}{ REACTOR R1 - without carbon source } \\
\hline & 1 & 2 & 3 & 4 & 5 & 6 & 7 \\
\hline Parameters & $\begin{array}{c}\text { Raw } \\
\text { wastewater }\end{array}$ & $\begin{array}{c}\text { Poured } \\
\text { wastewater } \\
(20 \mathrm{~min}) \\
\text { after } 20 \mathrm{~min}\end{array}$ & $\begin{array}{l}\text { Denitrification } \\
\text { (20 min) } \\
\text { after } 40 \mathrm{~min}\end{array}$ & $\begin{array}{l}\text { Denitrification } \\
\text { (20 min) } \\
\text { after } 60 \mathrm{~min}\end{array}$ & $\begin{array}{l}\text { Nitrification } \\
\quad(1.5 \mathrm{~h}) \\
\text { after } 2.5 \mathrm{~h}\end{array}$ & $\begin{array}{l}\text { Nitrification } \\
\qquad(2 \mathrm{~h}) \\
\text { after } 4.5 \mathrm{~h}\end{array}$ & $\begin{array}{c}\text { Decantation } \\
(0.5 \mathrm{~h}) \\
\text { after } 6 \mathrm{~h}\end{array}$ \\
\hline $\mathrm{COD}\left[\mathrm{mgO}_{2} / \mathrm{dm}^{3}\right]$ & 530 & 268 & 262 & 259 & 254 & 243 & 35 \\
\hline $\mathrm{BOD}_{5}\left[\mathrm{mgO}_{2} / \mathrm{dm}^{3}\right]$ & 230 & 125 & 120 & 120 & 115 & 98 & 6 \\
\hline Total nitrogen $\left[\mathrm{mgN} / \mathrm{dm}^{3}\right]$ & 118.0 & 84.0 & 68.7 & 55.2 & 48.1 & 24.3 & 14.4 \\
\hline Nitrate $\mathrm{NO}_{3}^{-}\left[\mathrm{mgN} / \mathrm{dm}^{3}\right]$ & 2.6 & 3.9 & 2.4 & 3.6 & 4.6 & 8.6 & 8.6 \\
\hline Ammonia $\mathrm{NH}_{4}{ }^{+}\left[\mathrm{mgN} / \mathrm{dm}^{3}\right]$ & 51.1 & 58.2 & 55.3 & 41.6 & 33.5 & 9.7 & 1.8 \\
\hline Phosphorus $\mathrm{PO}_{4}\left[\mathrm{mgP} / \mathrm{dm}^{3}\right]$ & 18.5 & 15.2 & 18 & 12.8 & 1.5 & 1.1 & 0.8 \\
\hline Phosphate $\mathrm{PO}_{4}\left[\mathrm{mgP} / \mathrm{dm}^{3}\right]$ & 18.5 & 15.2 & 18.0 & 12.8 & 1.5 & 1.1 & 0.8 \\
\hline
\end{tabular}




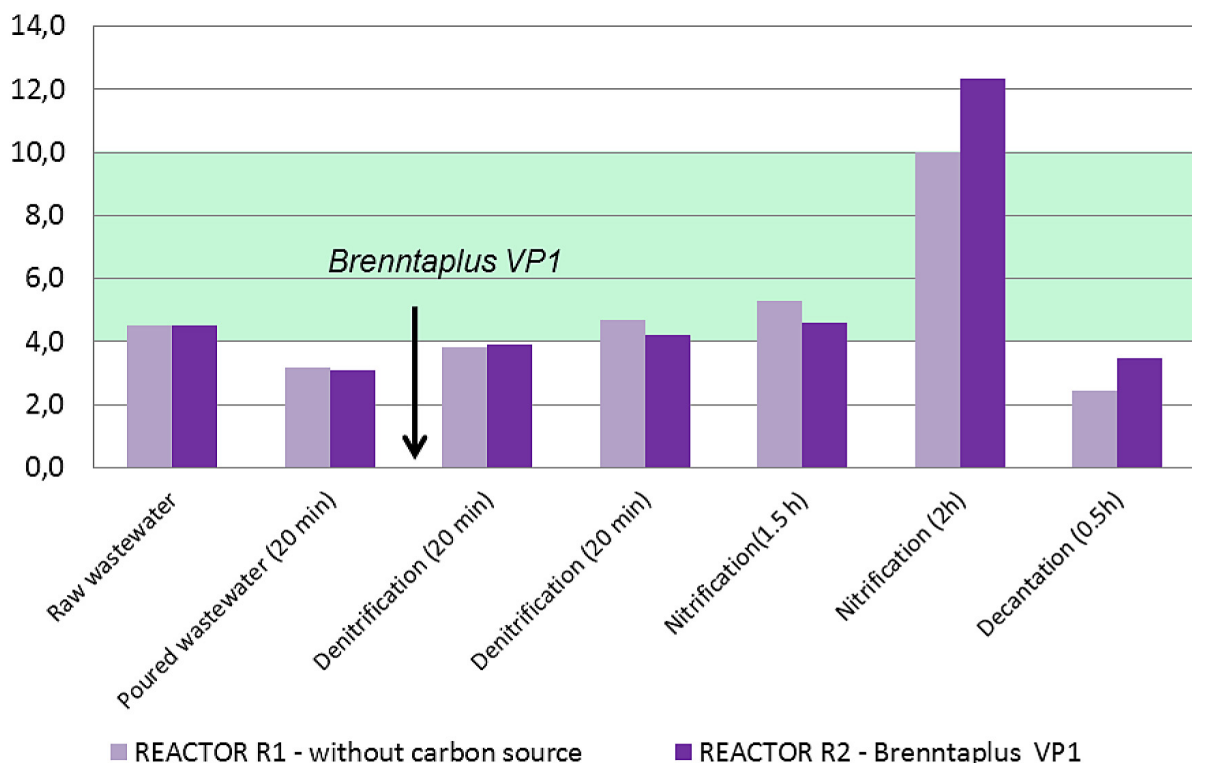

Figure 1. Concentrations the ratio of COD to nitrogen in control points.

Table 3. Data and test results of wastewater with addition of Brenntaplus VP1 as an external carbon source

\begin{tabular}{|c|c|c|c|c|c|c|c|}
\hline \multicolumn{8}{|c|}{ REACTOR R2 - Brenntaplus VP1 } \\
\hline \multirow[b]{3}{*}{ Parameters } & \multicolumn{7}{|c|}{ Dosage of carbon source } \\
\hline & 1 & 2 & 3 & 4 & 5 & 6 & 7 \\
\hline & $\begin{array}{c}\text { Raw } \\
\text { wastewater }\end{array}$ & $\begin{array}{c}\text { Poured } \\
\text { wastewater } \\
(20 \mathrm{~min}) \\
\text { after } 20 \mathrm{~min}\end{array}$ & $\begin{array}{l}\text { Denitrification } \\
\text { (20 min) } \\
\text { after } 40 \mathrm{~min}\end{array}$ & $\begin{array}{l}\text { Denitrification } \\
\text { (20 min) } \\
\text { after } 60 \mathrm{~min}\end{array}$ & $\begin{array}{l}\text { Nitrification } \\
(1.5 \mathrm{~h}) \\
\text { after } 2.5 \mathrm{~h}\end{array}$ & $\begin{array}{l}\text { Nitrification } \\
(2 \mathrm{~h}) \\
\text { after } 4.5 \mathrm{~h}\end{array}$ & $\begin{array}{c}\text { Decantation } \\
(0.5 \mathrm{~h}) \\
\text { after } 6 \mathrm{~h}\end{array}$ \\
\hline $\mathrm{COD}\left[\mathrm{mgO}_{2} / \mathrm{dm}^{3}\right]$ & 530 & 258 & 281 & 272 & 245 & 236 & 24 \\
\hline $\mathrm{BOD}_{5}\left[\mathrm{mgO}_{2} / \mathrm{dm}^{3}\right]$ & 230 & 125 & 120 & 115 & 110 & 96 & 5 \\
\hline Total nitrogen $\left[\mathrm{mgN} / \mathrm{dm}^{3}\right]$ & 118.0 & 84.0 & 72.1 & 64.4 & 53.4 & 19.1 & 6.9 \\
\hline Nitrate $\mathrm{NO}_{3}{ }^{-}\left[\mathrm{mgN} / \mathrm{dm}^{3}\right]$ & 2.6 & 4.4 & 2.1 & 2.4 & 12.7 & 11.3 & 5.4 \\
\hline Ammonia $\mathrm{NH}_{4}{ }^{+}\left[\mathrm{mgN} / \mathrm{dm}^{3}\right]$ & 51.1 & 41.9 & 43.4 & 38.3 & 16.5 & 3.6 & 0.5 \\
\hline Phosphorus $\mathrm{PO}_{4}\left[\mathrm{mgP} / \mathrm{dm}^{3}\right]$ & 18.5 & 15.2 & 16.9 & 17.6 & 3.1 & 0.8 & 0.8 \\
\hline Phosphates $\mathrm{PO}_{4}\left[\mathrm{mgP} / \mathrm{dm}^{3}\right]$ & 18.5 & 15.2 & 16.9 & 17.6 & 3.1 & 0.8 & 0.8 \\
\hline
\end{tabular}

Figures 2-4 illustrate the concentration of studied nitrogen forms after different stages of wastewater treatment.

Value of COD in raw wastewater amounted to $530 \mathrm{mgO}_{2} / \mathrm{dm}^{3}$, while $\mathrm{BOD}_{5} 230 \mathrm{mgO} / \mathrm{dm}^{3}$. Concentration of the total nitrogen in raw sewage was $118 \mathrm{mgN} / \mathrm{dm}^{3}$, ammonia $51.5 \mathrm{mgN} / \mathrm{dm}^{3}$ and nitrate $2.6 \mathrm{mgN} / \mathrm{dm}^{3}$.

Twenty minutes after the reactors filling, decreases in COD and $\mathrm{BOD}_{5}$ values were observed - the available carbon source was taken by denitrification bacteria. The value of COD in R1 reactor was $268.0 \mathrm{mgO}_{2} / \mathrm{dm}^{3}$, while the value of $\mathrm{BOD}_{5}$ equalled $125.0 \mathrm{mgO}_{2} / \mathrm{dm}^{3}$. In the reactor $\mathrm{R} 2$, the following values of parameters were recorded: $\mathrm{COD}-262.0 \mathrm{mgO} / \mathrm{dm}^{3}, \mathrm{BOD}_{5}-125 \mathrm{mgO} / \mathrm{dm}^{3}$. In both reactors, ammonia concentrations were the same, i.e. $84.0 \mathrm{mgN} / \mathrm{dm}^{3}$. The content of ni- trates in both reactors increased up to $3.9 \mathrm{mgN} /$ $\mathrm{dm}^{3}$ in R1 and to $4.4 \mathrm{mgN} / \mathrm{dm}^{3}$ in R2. The increase in the ammonia concentration was also recorded in $\mathrm{R} 1$ to $58.2 \mathrm{mgN} / \mathrm{dm}^{3}$, whereas the decrease in R2 amounted to $41.9 \mathrm{mgN} / \mathrm{dm}^{3}$.

Afterwards, Brenntaplus VP1 preparation was added as the external carbon source into the $\mathrm{R} 2$ reactor and after 20 minutes of denitrification process, subsequent samples were collected. In $\mathrm{R} 1$ reactor, where the wastewater treatment process proceeded without the support of an external carbon source, a further slight decrease in COD $\left(262 \mathrm{mgO} / \mathrm{dm}^{3}\right)$ and $\mathrm{BOD}_{5}\left(120 \mathrm{mgO}_{2} / \mathrm{dm}^{3}\right)$ was noted. Introducing the carbon source in the form of Brenntaplus VP1 caused the increase in the COD value in $\mathrm{R} 2$ reactor by $23.0 \mathrm{mgO}_{2} / \mathrm{dm}^{3}$, up to $281.0 \mathrm{mgO}_{2} / \mathrm{dm}^{3}$. The $\mathrm{BOD}_{5}$ value in $\mathrm{R} 2$ reactor decreased to $120 \mathrm{mgO}_{2} / \mathrm{dm}^{3}$. A decrease in the 


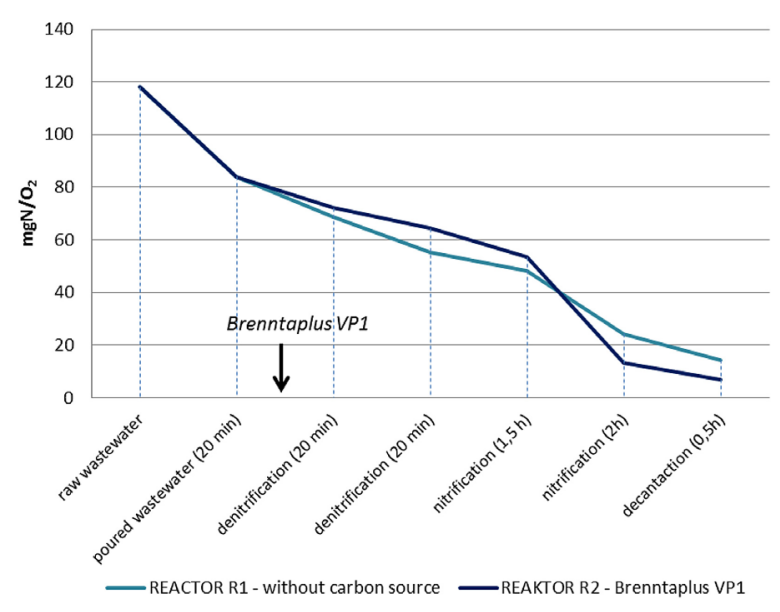

Figure 2. Concentrations of total nitogen after individual phases of wastewater treatment

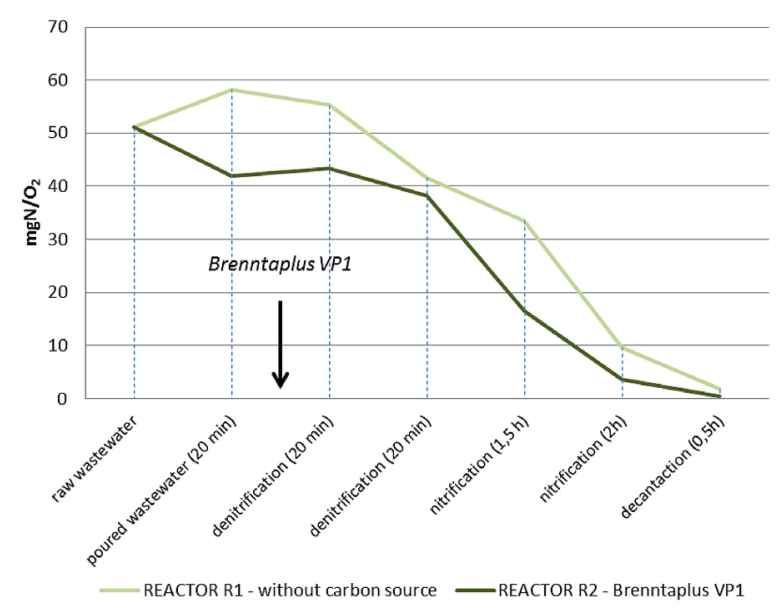

Figure 4. Concentrations of ammonia after individual phases of wastewater treatment

total nitrogen concentration in both reactors was recorded: in $\mathrm{R} 1-68.7 \mathrm{mgN} / \mathrm{dm}^{3}$, while in $\mathrm{R} 2-$ $72.1 \mathrm{mgN} / \mathrm{dm}^{3}$. In the case of nitrate, there were also lower concentrations as compared to the previous control point. In R1 reactor, the nitrate content was $2.4 \mathrm{mgN} / \mathrm{dm}^{3}$, while in $\mathrm{R} 2$ reactor -2.1 $\mathrm{mgN} / \mathrm{dm}^{3}$. The concentration of ammonia slightly decreased in R1 to $55.3 \mathrm{mgN} / \mathrm{dm}^{3}$, whereas in R2 reactor, the adverse situation was recorded - there was an increase in ammonia up to $43.4 \mathrm{mgN} / \mathrm{dm}^{3}$; however, the concentration was still lower than in $\mathrm{R} 1$ reactor.

After subsequent 20 minutes of anaerobic wastewater treatment process, a further slight decrease in COD in reactor $\mathrm{R} 1$ was found $\left(259 \mathrm{mgO}_{2} /\right.$ $\left.\mathrm{dm}^{3}\right)$. The value of $\mathrm{BOD}_{5}$ remained unchanged $\left(120 \mathrm{mgO}_{2} / \mathrm{dm}^{3}\right)$. In the reactor with Brenntaplus VP1 addition, the COD decrease by $9 \mathrm{mgO}_{2} /$ $\mathrm{dm}^{3}$ to the level of $272 \mathrm{mgO} / \mathrm{dm}^{3}$ was observed. The $\mathrm{BOD}_{5}$ value decreased to $115 \mathrm{mgO}_{2} / \mathrm{dm}^{3}$.

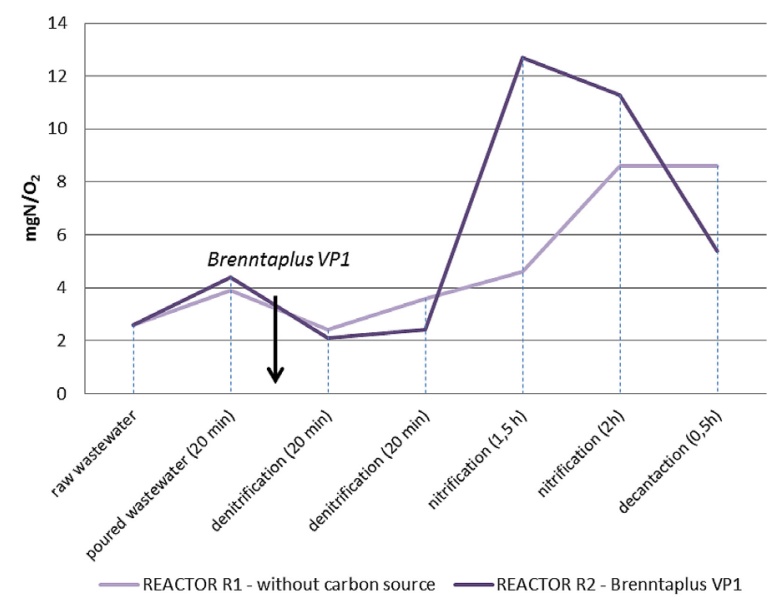

Figure 3. Concentrations of nitrate after individual phases of wastewater treatment

The concentration of the total nitrogen decreased further, reaching $55.2 \mathrm{mgN} / \mathrm{dm}^{3}$ in R1reactor. For R2 reactor with addition of Brenntaplus VP1, the total nitrogen concentration was higher than in $\mathrm{R} 1$ reactor and amounted to $64.4 \mathrm{mgN} / \mathrm{dm}^{3}$ translating into the difference of $9.2 \mathrm{mgN} / \mathrm{dm}^{3}$ total nitrogen between the reactors. In both reactors, an increase in the content of nitrates to $3.6 \mathrm{mgN} / \mathrm{dm}^{3}$ was recorded in R1 and $2.4 \mathrm{mgN} / \mathrm{dm}^{3}$ in R2. The ammonia level decreased in R1 to $41.6 \mathrm{mgN} / \mathrm{dm}^{3}$, while in R2 - to $38.3 \mathrm{mgN} / \mathrm{dm}^{3}$. The difference of the ammonia concentrations at that control point between the reactor without carbon source $\mathrm{R} 1$ and with molasses in R2 amounted to $3.3 \mathrm{mgN} / \mathrm{dm}^{3}$.

Other samples were collected after 1.5 hours of wastewater aeration. The value of COD in $\mathrm{R} 1$ reactor was $254 \mathrm{mgO}_{2} / \mathrm{dm}^{3}$, while $\mathrm{BOD}_{5}-$ $115 \mathrm{mgO}_{2} / \mathrm{dm}^{3}$. In $\mathrm{R} 2$ reactor, the decrease of COD value by $27 \mathrm{mgO}_{2} / \mathrm{dm}^{3}$ to the level of 245 $\mathrm{mgO}_{2} / \mathrm{dm}^{3}$ and the reduction of the $\mathrm{BOD}_{5}$ value to $110 \mathrm{mgO}_{2} / \mathrm{dm}^{3}$ occurred. Moreover, total nitrogen concentration was lower in the reactor without carbon source, amounting to $48.1 \mathrm{mgN} / \mathrm{dm}^{3}$ in $\mathrm{R} 1$ reactor. In the case of $\mathrm{R} 2$ reactor, the concentration of the total nitrogen was $53.4 \mathrm{mgN} /$ $\mathrm{dm}^{3}$. The difference between total nitrogen levels between $\mathrm{R} 1$ and $\mathrm{R} 2$ reactors was $5.3 \mathrm{mgN} / \mathrm{dm}^{3}$. The concentration of nitrates in R1 increased up to $4.6 \mathrm{mgN} / \mathrm{dm}^{3}$, which resulted from the inhibition of denitrification process due to the supply of oxygen into reactors. In R2 reactor, an increase in nitrates concentration was recorded as well, but these were higher values - even as high as $12.7 \mathrm{mgN} / \mathrm{dm}^{3}$. Such a high concentration was due to the intensive removal of ammonia nitrogen, which in the $\mathrm{R} 2$ reactor amounted only to $16.5 \mathrm{mgN} / \mathrm{dm}^{3}$ (decrease by $21.8 \mathrm{mgN} / \mathrm{dm}^{3}$ ). The 
concentration of ammonia nitrogen in $\mathrm{R} 1$ reactor decreased to $33.5 \mathrm{mgN} / \mathrm{dm}^{3}$ (by $8.1 \mathrm{mgN} / \mathrm{dm}^{3}$ ).

Subsequent samples were collected after another 2 hours of wastewater aeration. The value of COD in R1 reactor was $243.0 \mathrm{mgO}_{2} / \mathrm{dm}^{3}$. In the reactor with Brenntaplus VP1, there was further intake of available organic compounds, which resulted in lower COD values $\left(236.0 \mathrm{mgO}_{2} / \mathrm{dm}^{3}\right)$ than in the reactor without carbon source addition. The $\mathrm{BOD}_{5}$ value amounted to $98.0 \mathrm{mgO}_{2} / \mathrm{dm}^{3}$ in $\mathrm{R} 1$ reactor and to $96.0 \mathrm{mgO} / \mathrm{dm}^{3}$ in $\mathrm{R} 2$.

The concentration of the total nitrogen in R1 reactor was determined as $24.3 \mathrm{mgN} / \mathrm{dm}^{3}$. For $\mathrm{R} 2$ reactor, the concentration of total nitrogen was $19.1 \mathrm{mgN} / \mathrm{dm}^{3}$. The difference in the total nitrogen between both reactors amounted to $5.2 \mathrm{mgN} /$ $\mathrm{dm}^{3}$. Nitrate concentration in R1 was decreased to $8.6 \mathrm{mgN} / \mathrm{dm}^{3}$, in $\mathrm{R} 2$ reactor a further removal of $1.4 \mathrm{mgN} / \mathrm{dm}^{3}$ was noted. A long duration of wastewater aeration resulted in a significant lowering the ammonia concentration in both reactors as compared to the previous control point. The difference in the ammonia content between R1 reactor without carbon source - and R2 - with glycerin - was $6.1 \mathrm{mgN} / \mathrm{dm}^{3}$.

The value of COD in the treated wastewater from R1 reactor after decantation process amounted to $35.0 \mathrm{mgO}_{2} / \mathrm{dm}^{3}$, while the value of $\mathrm{BOD}_{5}$ was $6.0 \mathrm{mgO}_{2} / \mathrm{dm}^{3}$. Despite the addition of the external carbon source, the COD value in the treated sewage with Brenntaplus VP1 addition amounted to $24.0 \mathrm{mgO}_{2} / \mathrm{dm}^{3}$, whereas $\mathrm{BOD}_{5}-5.0$ $\mathrm{mgO}_{2} / \mathrm{dm}^{3}$. These are lower numbers than in R1 reactor, where no additional carbon source was used. The concentration of the total nitrogen in the treated wastewater from $\mathrm{R} 1$ reactor amounted to $14.4 \mathrm{mgN} / \mathrm{dm}^{3}$, ammonia $1.8 \mathrm{mgN} / \mathrm{dm}^{3}$, and nitrates $8.6 \mathrm{mgN} / \mathrm{dm}^{3}$. Treatment of wastewater in $\mathrm{R} 1$ reactor caused the removal of total nitrogen in $87.8 \%$ and ammonia in $96.5 \%$. In the case of the reactor with Brenntaplus VP1 addition, the concentration of the total nitrogen in the treat- ed wastewater was $6.9 \mathrm{mgN} / \mathrm{dm}^{3}$, ammonia 0.5 $\mathrm{mgN} / \mathrm{dm}^{3}$ and nitrate $5.4 \mathrm{mgN} / \mathrm{dm}^{3}$. Treating the sewage in R2 reactor resulted in the removal of total nitrogen in $94.2 \%$, while ammonia was removed in 99\%. The use of Brenntaplus VP1 in R2 reactor has resulted in a higher efficiency of the wastewater treatment process than in $\mathrm{R} 1$ reactor, where no external carbon source was applied. Despite the increase in the final nitrate concentration in $\mathrm{R} 1$ and $\mathrm{R} 2$ reactors, the reactor with external carbon source addition contained lower nitrate concentration by $3.2 \mathrm{mgN} / \mathrm{dm}^{3}$.

Pearson's linear correlation was calculated to determine the correlation between the individual indicators. The Statistica 12 software was used to develop the results. The calculations included the analysis of Pearson's correlation coefficients at $\mathrm{p}<0.05$ to determine the degree of linear relationship between the raw sewage parameters and the reactor unit processes and COD fractions. The results are summarized in Table 4. According to calculated correlations, the strongest correlation values are between $\mathrm{COD}$ and $\mathrm{BOD}_{5}, \mathrm{COD}$ and total nitrogen, $\mathrm{BOD}_{5}$ and total nitrogen, total nitrogen and total phosphorus, total nitrogen and phosphates, total nitrogen and ammonia nitrogen, ammonia nitrogen and total phosphorus, ammonia nitrogen and phosphates, as well as total phosphorus and phosphates.

The denitrification rate along with the mean denitrification rate was determined twenty minutes after the addition of the carbon source (Figure 5). In the initial denitrification phase with the addition of an external carbon source in the form of Brenntaplus VP1, the removal of nitrogen compounds by $1.2 \mathrm{mgN} \cdot \mathrm{dm}^{3} / \mathrm{h}$ was observed, as compared to the control reactor. For the mean denitrification rate in the reactor without the addition of carbon source, the speed was much lower and amounted to only $0.3 \mathrm{mgN} \cdot \mathrm{dm}^{3} / \mathrm{h}$, while the speed difference between the two reactors was $1.7 \mathrm{mgN} \cdot \mathrm{dm}^{3} / \mathrm{h}$.

Table 4. Pearson's linear correlation coefficients

\begin{tabular}{|l|c|c|c|c|c|c|c|c|c|}
\hline \multicolumn{1}{|c|}{ Parameters } & Means & Std. Dev. & $\mathrm{COD}$ & $\mathrm{BOD}_{5}$ & $\begin{array}{c}\text { Total } \\
\text { nitrogen }\end{array}$ & Nitrate & Ammonia & $\begin{array}{c}\text { Total } \\
\text { phosphorus }\end{array}$ & Phosphate \\
\hline $\mathrm{COD}$ & 264.071 & 139.690 & 1.00000 & 0.99466 & 0.88034 & -0.41570 & 0.68944 & 0.66627 & 0.66452 \\
\hline $\mathrm{BOD}_{5}$ & 115.357 & 62.867 & 0.99466 & 1.00000 & 0.90662 & -0.43949 & 0.73934 & 0.69469 & 0.69309 \\
\hline Total nitrogen & 59.329 & 35.268 & 0.88034 & 0.90662 & 1.00000 & -0.61858 & 0.87955 & 0.86438 & 0.86268 \\
\hline Nitrate & 5.371 & 3.511 & -0.41570 & -0.43949 & -0.61858 & 1.00000 & -0.77977 & -0.79810 & -0.79836 \\
\hline Ammonia & 31.893 & 21.066 & 0.68944 & 0.73934 & 0.87955 & -0.77977 & 1.00000 & 0.90319 & 0.90274 \\
\hline $\begin{array}{l}\text { Total } \\
\text { phosphorus }\end{array}$ & 10.129 & 8.053 & 0.66627 & 0.69469 & 0.86438 & -0.79810 & 0.90319 & 1.00000 & 0.99998 \\
\hline Phosphate & 10.057 & 7.984 & 0.66452 & 0.69309 & 0.86268 & -0.79836 & 0.90274 & 0.99998 & 1.00000 \\
\hline
\end{tabular}




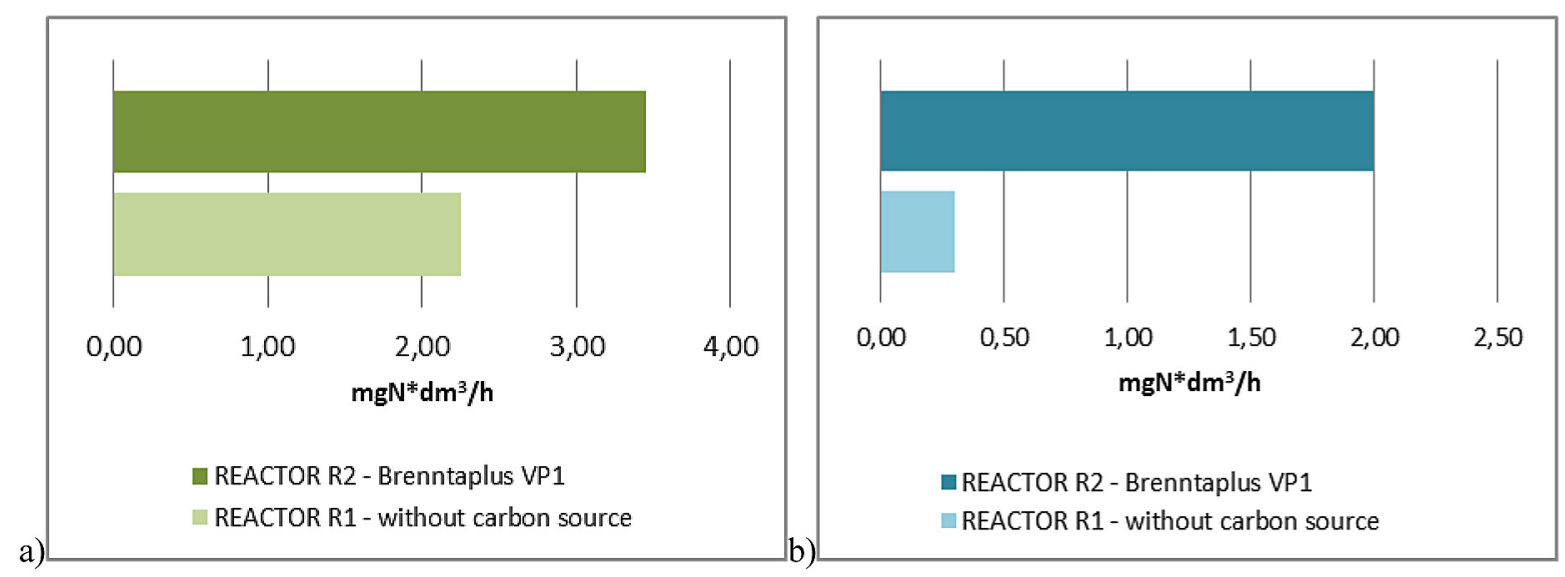

Figure 5. Denitrification rate a) twenty minutes after addition of the carbon source b) average denitrification rate

\section{CONCLUSION}

1. The use of glycerin as an external source of carbon during wastewater treatment has resulted in a higher removal efficiency of nitrogen forms than in the reactor where no external carbon source has been applied along with low COD content in the purified wastewater.

2. Despite the increase in nitrate concentration in the sewage treated in both reactors, the use of molasses has resulted in a decrease in the concentration of nitrates in purified wastewater by $3.2 \mathrm{mgN} / \mathrm{dm}^{3}$ as compared to reactor without supply the external carbon source.

3. Addition of Brenntaplus VP1 resulted in an accelerated denitrification by $1.7 \mathrm{mgN} \cdot \mathrm{dm}^{3}$, as compared to the control reactor.

\section{Acknowledgements}

The project was financed by the National Science Centre (W/WBiIS/9/2016).

\section{REFERENCES}

1. Brenntaplus VP1 - Zwiększenie skuteczności usuwania biogenów. http://www.brenntag.com/poland/pl/index.jsp.

2. Cherchi C., Onnis-Hayden A., El-Shawabkeh I. N., $\mathrm{Gu}$ A. 2009. Implication of using different carbon sources for denitrification in wastewater treatments Water Environment Research, 81(8), 788-799.

3. Dinçer K., Kargi F. 2000. Effects of operating parameters on performances of nitrification and denitrification processes. Bioprocess Engineering, 23, 75-80.

4. Elefsiniotis P., Li D. 2006. The effect of tempera- ture and carbon source on denitrification using volatile fatty acids, Biochemical Engineering Journal 28, 148-155.

5. Henze M. 1991, Capabilities of biological nitrogen removal processes from wastewater, Wat. Sci. Technol. 23, 669-679.

6. Ignatowicz K., Piekarski J., Kozłowski D. 2015. Wspomaganie procesu denitryfikacji preparatem Brentaplus VP1 jako zewnętrznym źródłem węgla, Rocznik Ochrona Środowiska, 17, 1178-1195 (in Polish).

7. Kaszubowska M., Majtacz J., Mąkinia J., Czerwionka K., Kulbat E. 2011, Badania kinetyczne procesu denitryfikacji $\mathrm{z}$ dawkowaniem zewnętrznego źródła węgla $\mathrm{z}$ postaci produktów odpadowych $\mathrm{z}$ produkcji alkoholu. Zeszyty Naukowe. Inżynieria Środowiska, 141, 78-86 (in Polish).

8. Kogut P., Piekarski J., Ignatowicz K., 2014, Start-up of Biogas Plant with Inoculating Sludge Application. Rocznik Ochrona Środowiska, 16, 534-545.

9. Liu F., Tian Y., Ding Y., Li Z. 2016. The use of fermentation liquid of wastewater primary sedimentation sludge as supplemental carbon source for denitrification based on enhanced anaerobic fermentation, Bioresource Technology, 219, 6-13.

10. Łomotowski J., Szpindor A. 1999, Nowoczesne systemy oczyszczania ścieków, Arkady, Warszawa (in Polish).

11. Oleszkiewicz J.A., Kalinowska E., Dold P., Barnard J.L., Bieniowski M., Ferenc Z., Jones R., Rypina A. i Sudol J. (2004) Feasibility studies and pre-design simulation of Warsaw's new wastewater treatment plant, Environmental Technology, 25, 1405-1411.

12. Plüg B.D., Cibati A., Trois C. 2015. The use of organic wastes at different degrees of maturity as carbon sources for denitrification of landfill leachate, Waste Management, 46, 373-37. 
13. Shi Y., Wu G., Wei N., Hu H. 2015. Denitrification and biofilm growth in a pilot-scale biofilter packed with suspended carriers for biological nitrogen removal from secondary effluent, Journal of Environmental Sciences, 32, 35-41.

14. Simson G. 2009. Intensyfikacja procesu denitryfikacji w Oczyszczalni ścieków w Białymstoku poprzez dozowanie preparatu Brenntaplus VP1 jako zewnętrznego źródła węgla organicznego doświadczenia eksploatacyjne (część 2) Forum Eksploatatora, 6, 49-52 (in Polish).

15. Smyk J., Ignatowicz K. 2017, The influence of mo- lasses on nitrogen removal in wastewater treatment with activated sludge, Journal of Ecological Engineering, 18, 199-203.

16. Sun H., Wu Q., Yu P., Zhang L., Ye L., Xu-Xiang. 2017. Denitrification using excess activated sludge as carbon source: Performance and the microbial community dynamics, Bioresource Technology, 238, 624-632.

17. Zhang Y., Wang X.C., Cheng Z., Li Y., Tang J. 2016, Effect of fermentation liquid from food waste as a carbon source for enhancing denitrification in wastewater treatment, Chemosphere, 144, 689-696. 